\title{
Pathogenesis of reproductive failure induced by Trypanosoma vivax in experimentally infected pregnant ewes
}

\author{
Taciana MF Silva ${ }^{1}$, Roberio G Olinda', Carla MF Rodrigues², Antônio CL Câmara', Francisco C Lopes', \\ Wesley AC Coelho', Múcio FB Ribeiro ${ }^{3}$, Carlos IA Freitas ${ }^{1}$, Marta MG Teixeira ${ }^{2}$ and Jael S Batista ${ }^{1 *}$
}

\begin{abstract}
The present study was aimed at investigating the effect of experimental infection by Trypanosoma vivax in different stages of pregnancy, determining the pathogenesis of reproductive failure, and confirming transplacental transmission. We used 12 pregnant ewes distributed into four experimental groups: G1, was formed by three ewes infected with T. vivax in the first third of pregnancy (30 days); G2 comprised three infected ewes in the final third of pregnancy (100 days); G3 and G4 were composed of three non-infected ewes with the same gestational period, respectively. Each ewe of G1 and G2 was inoculated with $1.25 \times 10^{5}$ tripomastigotes. Clinical examination, determination of parasitemia, serum biochemistry (albumin, total protein, glucose, cholesterol, and urea), packed cell volume (PCV), serum progesterone, and pathological examination were performed. Placenta, amniotic fluid, blood and tissues from the fetuses and stillbirths were submitted to PCR. Two ewes of G1 (Ewe 1 and 3) presented severe infection and died in the $34^{\text {th }}$ and $35^{\text {th }}$ days post-infection (dpi), respectively; but both fetuses were recovered during necropsy. In G2, Ewe 5 aborted two fetuses on the $130^{\text {th }}$ day (30 dpi) of pregnancy; and Ewe 6 aborted one fetus in the $140^{\text {th }}$ day ( $40 \mathrm{dpi}$ ) of gestation. Ewes 2 and 4 delivered two weak lambs that died five days after birth. Factors possibly involved with the reproductive failure included high parasitemia, fever, low PCV, body score, serum glucose, total protein, cholesterol, and progesterone. Hepatitis, pericarditis, and encephalitis were observed in the aborted fetuses. The presence of T. vivax DNA in the placenta, amniotic fluid, blood, and tissues from the fetuses confirms the transplacental transmission of the parasite. Histological lesion in the fetuses and placenta also suggest the involvement of the parasite in the etiopathogenesis of reproductive failure in ewes.
\end{abstract}

\section{Introduction}

Trypanosomiasis is a disease caused by the pathogenic protozoa of the genus Trypanosoma. This parasite has a wide distribution and economic importance in African countries, mainly in regions occupied by its biological vector, the tsetse fly [1]. In West Africa, Trypanosoma vivax is considered the most important and pathogenic hemoparasite of livestock promoting reproductive disorders $[2,3]$.

The cyclical transmission through the salivary vector (tsetse fly) is the main mechanism of transmission. In this type of transmission, the parasite completes its entire development cycle in the proboscis of the vector,

\footnotetext{
* Correspondence: jaelsoares@hotmail.com

'Department of Animal Sciences, Federal Rural University of the Semiarid (UFERSA), Av. Francisco Mota 572, Mossoró, RN 59625-900, Brazil

Full list of author information is available at the end of the article
}

culminating in the development of metacyclic trypomastigotes, which are infective to the vertebrate host when inoculated with the saliva through the bite of the fly [4]. In contrast, T. vivax found in South America is mechanically transmitted only by blood sucking insects of the Tabanidae and Stomoxydae families. These insects act only as carriers and any stage of the parasite cycle of the parasite occurs within the vector. Trypanosomiasis may still be artificially transmitted through the shared use of a needle for several animals during application of medications or vaccinations $[5,6]$. The adaptation to mechanical transmission has been responsible for the rapid spread and wide geographical distribution of the parasite in areas free of the tsetse fly [7]. Therefore, the presence of T. vivax in cattle has already been reported in French

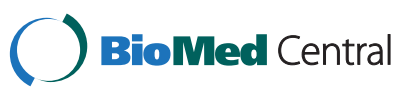

(c) 2013 Silva et al.; licensee BioMed Central Ltd. This is an Open Access article distributed under the terms of the Creative Commons Attribution License (http://creativecommons.org/licenses/by/2.0), which permits unrestricted use, distribution, and reproduction in any medium, provided the original work is properly cited. 
Guiana [8], the Atlantic Coast of Colombia [9,10], Bolivia [2,11], and Brazil [12-14].

Despite the evidence of vertical transmission (transplacental) of T. vivax in cattle and sheep [15], the precise epidemiological importance of this type of transmission is still unknown. There is speculation that transplacental transmission is associated with the occurrence of abortions, prematurity, intrauterine growth retardation and perinatal mortality [16,17]. Recent studies demonstrate that the trypanosomiasis by $T$. vivax in the semiarid region of Brazil is a debilitating disease, promoting economic losses and serious infection with prevalence reaching $33.8 \%, 29.7 \%$ and $25.4 \%$ in cattle, goats and sheep, respectively $[18,19]$. In a high-mortality outbreak of trypanosomiasis in extensively raised ewes in a nonendemic region in Northeastern Brazil, perinatal mortality due to abortions and neonatal deaths reached nearly $75 \%$ [20]. Perinatal mortality was also one of the main manifestations during outbreaks in cattle from other municipalities located in the same region. The authors suggest that transplacental transmission has epidemiological significance for the maintenance and spread of disease in infected herds of ruminants [15].

Despite the evidence of the negative effect of trypanosomiasis caused by $T$. vivax on the reproduction of ruminants, there are still gaps that need to be filled about the pathogenesis of reproductive failure. Thus, the objective of this study was to investigate the effect of an experimental infection with $T$. vivax in pregnant ewes at different stages of pregnancy, to determine the pathogenesis of abortion, and to confirm transplacental transmission by PCR.

\section{Materials and methods}

\section{Design of the experimental groups}

Twelve, approximately 24 month-old pregnant ewes were used. The animals were housed in properly screened individual stalls at the premises of the Center for Studies and Research in Small Ruminants of the Federal Rural University of the Semiarid (UFERSA), Mossoró, Rio Grande do Norte, Brazil.

The study was approved by the Ethics Committee of the Federal Rural University of the Semiarid. Ethical procedures were based on the Brazilian law 6638 (May 8, 1979) "Normas para Prática Didático-Científica da Vivissecção de Animais" and "Ethical Principles for Use of Experimental Animals" from the Brazilian College of Animal Experimentation (COBEA), Brazil, which are in accordance with the "European Convention for the Protection of Vertebrate Animals used for Experimental and Other Scientific Purposes" (Strasbourg, March 18, 1986).

Ultrasonographic exams were performed to identify the gestation period using a $3.5 \mathrm{MHz}$ or $5 \mathrm{MHz}$ abdominal transducer connected to a Logiq Pro 100 GE ultrasound.
We estimated the gestational age of the sheep in the initial third using the length of the embryonic vesicle. These animals were infected in the $30^{\text {th }}$ day of pregnancy. The final third of gestation was estimated by the cephalo-coccygeal length of the fetuses, and those ewes were infected in the $100^{\text {th }}$ day of gestation.

Fourteen days before the inoculation of T. vivax, the ewes were clinically evaluated and dewormed. Hematological exams were also performed. Then, the animals were allocated into four experimental groups by random selection: Group 1 (G1) was formed by three ewes infected in the first third of pregnancy (Ewes 1, 2, and 3); Group 2 (G2) consisted of three ewes infected in the final third of pregnancy (Ewes 4, 5, and 6); Group 3(G3) was formed by three noninfected ewes with the same gestational period of ewes in G1 corresponding to the control group of this group (Ewes 7, 8, 9); and Group 4 (G4) was composed of three noninfected ewes (Ewes 10,11,12) with the same gestational period of ewes in G2 corresponding to the control group of this group. All animals were submitted to identical management conditions, fed with water and Tifton (Cynodon sp.) hay ad libitum, and supplemented with commercial concentrate (1.5\% BW/day/ewe).

\section{Inoculum preparation and experimental infection with T. vivax}

The strain of T. vivax used for experimental infection of the ewes in this study was derived from a natural outbreak in ewes from the city of São João do Rio do Peixe, Paraíba, Northeastern Brazil [20]. Blood samples were collected from ewes with parasitemia in $10 \%$ ethylenediaminetetraacetic acid disodium (EDTA) mixed with $8 \%$ glycerol, and frozen in liquid nitrogen $\left(-196^{\circ} \mathrm{C}\right)$. Immediately before inoculation, the strain sample was defrosted at room temperature. Each ewe from the experimental group was inoculated intravenously with $1 \mathrm{~mL}$ of blood containing $1.25 \times 10^{5}$ trypomastigotes of $T$. vivax, which was estimated according to Batista et al. [18].

\section{Determination of parasitemia and hematocrit}

Parasitemia was determined daily by research of the trypanosome in the blood collected from small blood vessels located in the ear, using a blood smear between the slide and coverslip, according to the technique described by Batista et al. [18]. The evaluation of hematocrit was performed daily by microcentrifugation.

\section{Clinical examination of the ewes and weight of the newborns and aborted fetuses}

Experimental ewes were examined daily to assess rectal temperature, status of the mucous membrane, and external lymph nodes, and were checked for signs of labor or abortion. Body score was determined weekly using a scale of 0 (for very thin animals) to 5 (for fat animals) 
[21]. At the beginning of the experiment, all ewes were classified with the help of body condition scores ranging from 3.5 to 4 . Immediately after delivery or abortion, newborns and fetuses were measured and weighed with an electronic digital scale.

\section{Serum biochemistry and analysis of progesterone}

In weekly intervals, blood was obtained by jugular vein puncture, and placed in sterile tubes containing $10 \%$ EDTA for the determination of serum biochemistry. Albumin, total protein, glucose, cholesterol, and urea were determined using commercial kits (Katal, Belo Horizonte, MG, Brazil) and an automatic analyzer SBA-2000 (Celm, Barueri, SP, Brazil). A blood sample was also placed in sterile Vacutainer tubes for determination of plasma progesterone by microparticle enzyme immunoassay (Immulite 2000, PRG, Progesterona, Siemens Healthcare Diagnostics Products Limited).

\section{Pathological and histopathological studies}

Pathological examination of the aborted fetuses, stillborns, placenta, and umbilical cords was performed. Fragments from thoracic and abdominal organs, and the central nervous system from the fetuses and stillborns were fixed in $10 \%$ buffered formalin and then embedded in paraffin. Sections of $5.0 \mu \mathrm{m}$ were cut using a microtome, and stained using the classical hematoxylin-eosin method (HE).

\section{Diagnosis of $T$. vivax by PCR}

Samples from amniotic fluid $(1 \mathrm{~mL})$ and fragments of approximately $1 \mathrm{~cm}^{3}$ of each placenta, stillborn and aborted fetus organs were collected, and preserved in 99\% ethanol. The DNA preparations were subjected to a highly sensitive PCR assay specific for T. vivax standardized by Cortez et al. [22]. This PCR method targets repeated gene sequences that encode cysteine proteases (Cathepsin L) and was carried out using the oligonucleotides Tvi2 (forward: 5' GCC ATC GCC AAG TAC CTC GCC GA 3') and DTO156 (reverse: 5' TTAGAATTCC CAGGAGTTCTTGATGATCCAGTA 3') as primers. The diagnosis was confirmed by PCR and amplifying a DNA fragment of about 177 base pairs (bp) that is also observed in the DNA of T. vivax (from Catolé do Rocha, Paraiba, Northeastern Brazil), which was used as a positive control. DNA samples from amniotic fluid, blood, and tissues of the non-infected ewes (G3 and G4) were used as negative controls.

\section{Statistical analysis}

Data were expressed as mean \pm standard error, and analyzed by SAS statistical software (SAS Institute Inc., Cary, North Carolina, USA) version 9.0, and Minitab (Minitab Inc. LEAD Technologies), version 16.1.1. Primarily, the data were assessed for normality by Lilliefors (KolmogorovSmirnov) and homogeneity by Levene. Statistical difference between the values of the infected groups G1 and G2, with their respective controls (G3 and G4) were calculated by the independent $\mathrm{t}$ test when showing normality, and by Mann- Whitney test when not-normal. $P<0.05$ was considered significant. In G1 and G3, statistical analysis comprised until the $34^{\text {th }}$ day post-infection (dpi) (64 days of pregnancy) period in which all the ewes in G1 were still alive.

\section{Results}

\section{Mean parasitemia}

The period after inoculation of T. vivax and the onset of parasitemia (pre-patent period) was three days, and remained high throughout the experimental period, and achieved the peak of parasitemia on the $43^{\text {rd }}(13 \mathrm{dpi})$ and $115^{\text {th }}$ (15 dpi) days of gestation in G1 and G2, respectively.

\section{Clinical signs and reproductive changes}

Hyperthermia was observed in G1 between 35 (5 dpi) and 53 (23 dpi) days of pregnancy with a significant difference $(P<0.05)$ compared to G3. In G2, hyperthermia was significantly different $(P<0.05)$ from $G 4$ between 105 (5 dpi) and 123 (23 dpi) days of gestation (Figures 1 and 2). Clinical signs included apathy, tachypnea, tachycardia, hyporexia, pale mucosae, and enlarged lymph nodes. Ewes 2 and 3 presented severe diarrhea between the $37^{\text {th }}(7 \mathrm{dpi})$ and $48^{\text {th }}(18 \mathrm{dpi})$ days of pregnancy. Ewes from both infected groups showed progressive weight loss. Ewes 1 and 3 presented a worsening of symptoms and showed prostration, weakness, lethargy, severe anemia (PCV minimum of $8.0 \%$ ), anorexia, and recumbence; dying in the $64^{\text {th }}$ and $65^{\text {th }}$ days of pregnancy

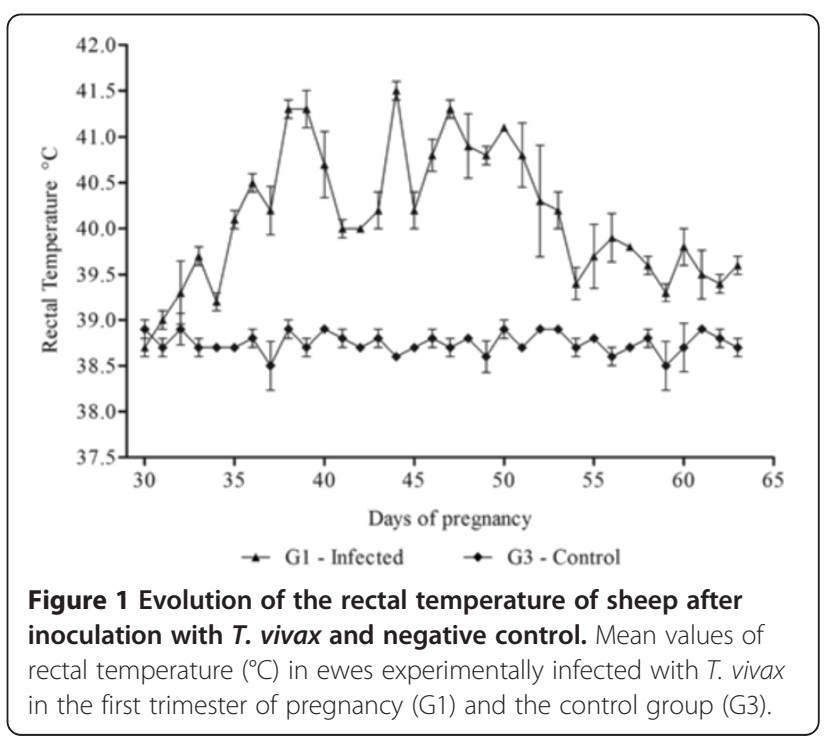




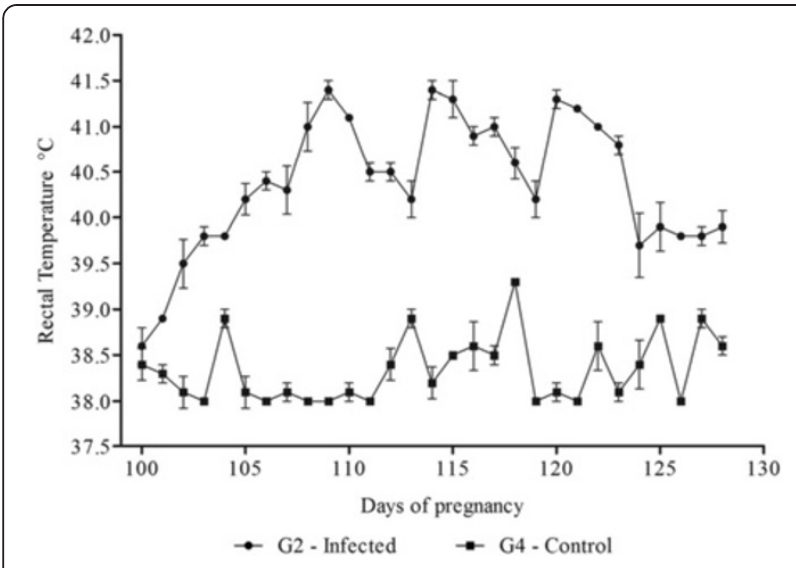

Figure 2 Evolution of the rectal temperature of sheep after inoculation with $T$. vivax and negative control. Mean values of rectal temperature $\left({ }^{\circ} \mathrm{C}\right)$ in ewes experimentally infected with $T$. vivax in the final trimester of pregnancy (G2) and the control group (G4).

( 34 and $35 \mathrm{dpi}$ ), respectively. These ewes presented body condition score of 1.5, whilst Ewe 2 presented a body score of 2. G2 (Ewes 4, 5 and 6) presented body condition score of 2 in the final days of the experiment. Ewes from G3 and G4 maintained the body score observed at the beginning of the trial.

Fetuses from the dead ewes (Ewe 1 and 3) were recovered during necropsy. The fetus from Ewe 1 was $7 \mathrm{~cm}$ in length and weighed $0.5 \mathrm{~kg}$; the fetus from Ewe 3 was the same length and $0.6 \mathrm{~kg}$. Ewes 2 and 4 delivered two weak lambs weighing 1.5 and $1.1 \mathrm{~kg}$, and measuring 23 and $21 \mathrm{~cm}$, respectively. These ewes had a poorly developed udder and agalactia. So the lambs were not able to ingest colostrum, and died five days after birth. Approximately, on the $130^{\text {th }}$ day $(30 \mathrm{dpi})$ of pregnancy, Ewe 5 aborted two lambs that were nearly $25 \mathrm{~cm}$ in length and weighed 1.2 and $1.3 \mathrm{~kg}$. Ewe 6 also aborted a $23 \mathrm{~cm}$ and $1.5 \mathrm{~kg}$ fetus in the $140^{\text {th }}$ day ( $40 \mathrm{dpi}$ ) of gestation.

\section{Packed cell volume, serum biochemistry and analysis of progesterone}

Significant reduction $(P<0.05)$ in the mean $\mathrm{PCV}$ was observed in G1 and G2 compared to G3 and G4, respectively. The average PCV in the G3 and G4 remained within the normal parameters for the species during the whole experimental period. Our data showed that mean values of serum glucose, total protein, albumin and cholesterol decreased significantly $(P<0.05)$ in G1 compared with G3. Serum albumin level was the only serum parameter that decreased significantly $(P<0.05)$ in $\mathrm{G} 2$ compared with G4. There was a gradual increase in serum urea and a significant difference in mean values of G1 and G2, when compared to their respective control. In G2, a marked reduction in progesterone levels and a significant difference compared to G3 $(P<0.05)$ was also observed (Table 1).

\section{Pathological and histological studies}

Gross findings included enlarged, hemorrhagic, friable cotyledons and focal areas of necrosis in the placentas of Ewes 5 and 6. All aborted fetuses and stillbirths showed a moderate amount of sero-bloody fluid in the abdominal and thoracic cavity, and pericardial sac. Subcutaneous edema and congestion of the liver, kidneys, lungs, and brain were also noted. At the heart of one of the aborted fetuses, petechial hemorrhages and suffusions in the epicardium were observed.

Histologically, necrosis of the chorionic epithelium of the placentas of Ewes 5 and 6 was observed (Figure 3). In the liver of the aborted fetuses, hepatitis was characterized by multifocal lymphocytic inflammatory infiltrates, and diffuse hepatocellular necrosis (Figure 4). The presence of extensive pericarditis characterized by the inflammatory infiltration of lymphocytes and plasma cells; and multifocal lymphocytic encephalitis located in the white matter of the brain was also noted (Figure 5).

\section{Detection of parasite DNA in fetal tissue and placenta}

PCR analysis for $T$. vivax (TviCatL-PCR) showed the amplification of a DNA fragment of approximately $177 \mathrm{pb}$, specific of T. vivax, and retrieved from the cathalitic domain of the Catepsina L gene (visualized in $2 \%$ agarose gel). The samples resulted positive in the blood of the fetuses $(100 \%)$, placentas $(57.1 \%)$, amniotic fluid (28.6\%), heart $(28.6 \%)$, nervous system (14.3\%), kidneys $(14.3 \%)$ and testicles $(14.3 \%)$ of the fetuses. However, PCR was negative for all samples of the control group (Figure 6).

Table 1 Mean values \pm standard error for the infected and control groups according to the variables studied

\begin{tabular}{lllll}
\hline Variables & Period & Infected & Control & P value \\
\hline Glucose $(\mathrm{mg} / \mathrm{dl})$ & G1 & $38.0 \pm 7.71$ & $71.42 \pm 1.50$ & $0.008^{*}$ \\
& G2 & $49.25 \pm 9.62$ & $70.5 \pm 2.10$ & 0.14 \\
Total protein $(\mathrm{g} / \mathrm{dl})$ & G1 & $5.15 \pm 0.53$ & $7.07 \pm 0.08$ & $0.02^{*}$ \\
& G2 & $5.67 \pm 0.75$ & $7.12 \pm 0.13$ & 0.148 \\
Albumin $(\mathrm{g} / \mathrm{dl})$ & G1 & $2.30 \pm 0.19$ & $3.51 \pm 0.03$ & $0.0017^{*}$ \\
& G2 & $2.62 \pm 0.38$ & $3.52 \pm 0.04$ & $0.03^{*}$ \\
Cholesterol(mg/dl) & G1 & $54.28 \pm 5.26$ & $72.42 \pm 1.08$ & $0.015^{*}$ \\
& G2 & $61.5 \pm 9.64$ & $74.25 \pm 0.94$ & 0.24 \\
Urea $(\mathrm{mg}-\mathrm{dl})$ & G1 & $53.42 \pm 9.84$ & $14.42 \pm 0.94$ & $0.01^{*}$ \\
& G2 & $44.25 \pm 13.3$ & $13.5 \pm 1.55$ & $0.02^{*}$ \\
Progesterone $(\mathrm{ng} / \mathrm{dl})$ & G1 & $12.99 \pm 1.97$ & $17.4 \pm 0.69$ & 0.10 \\
& G2 & $9.56 \pm 2.80$ & $18.63 \pm 0.29$ & $0.007^{*}$ \\
\hline
\end{tabular}

* Meaningful statistical difference $(P<0.05)$. 


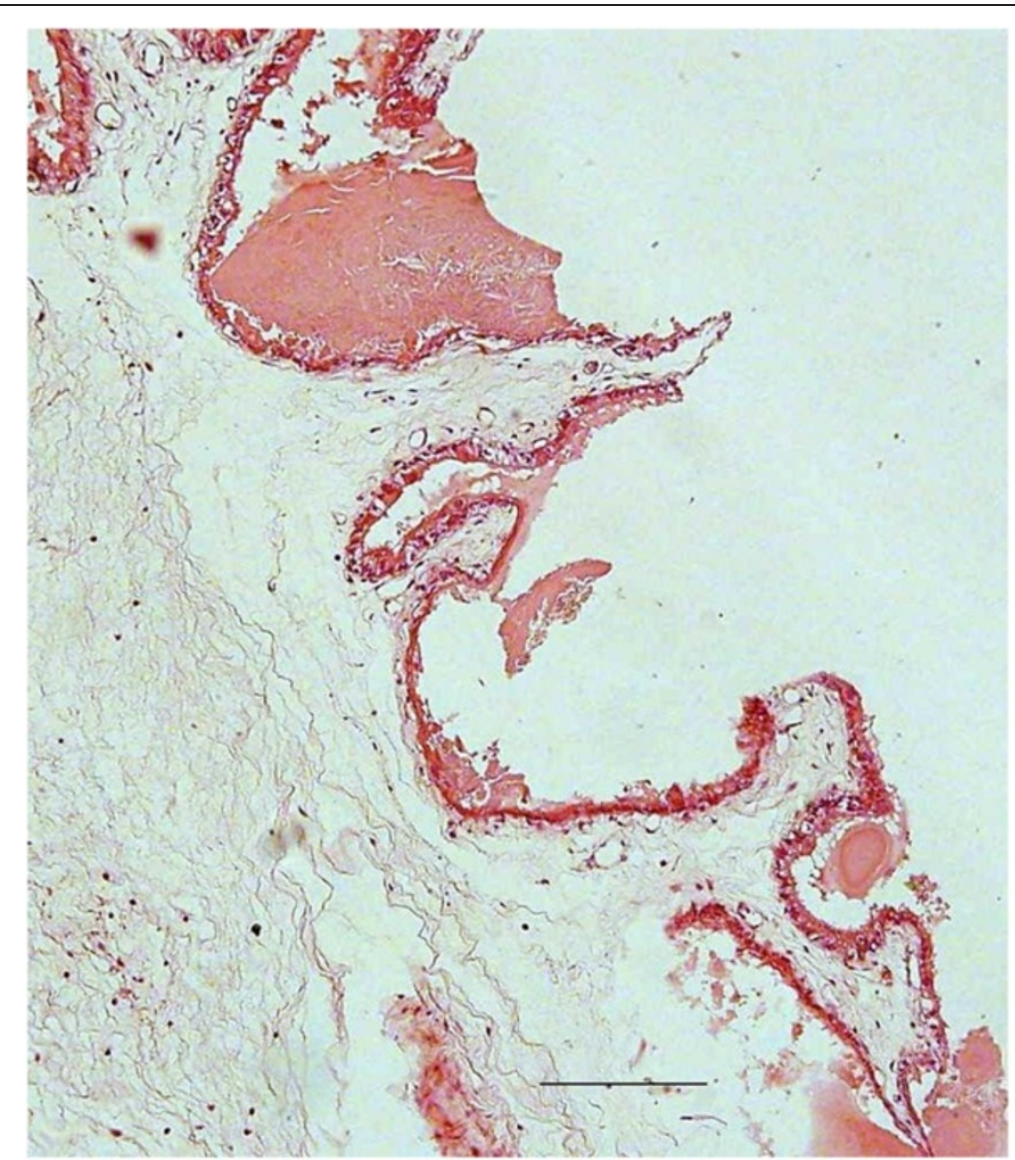

Figure 3 Placental injury induced by the presence of $\boldsymbol{T}$. vivax in sheep. Necrosis of the chorionic epithelium of the placenta of ewes experimentally infected with T. vivax in the final trimester of pregnancy. Hematoxilin-eosin, obj. 10x, Scale bar $=150 \mu \mathrm{m}$.

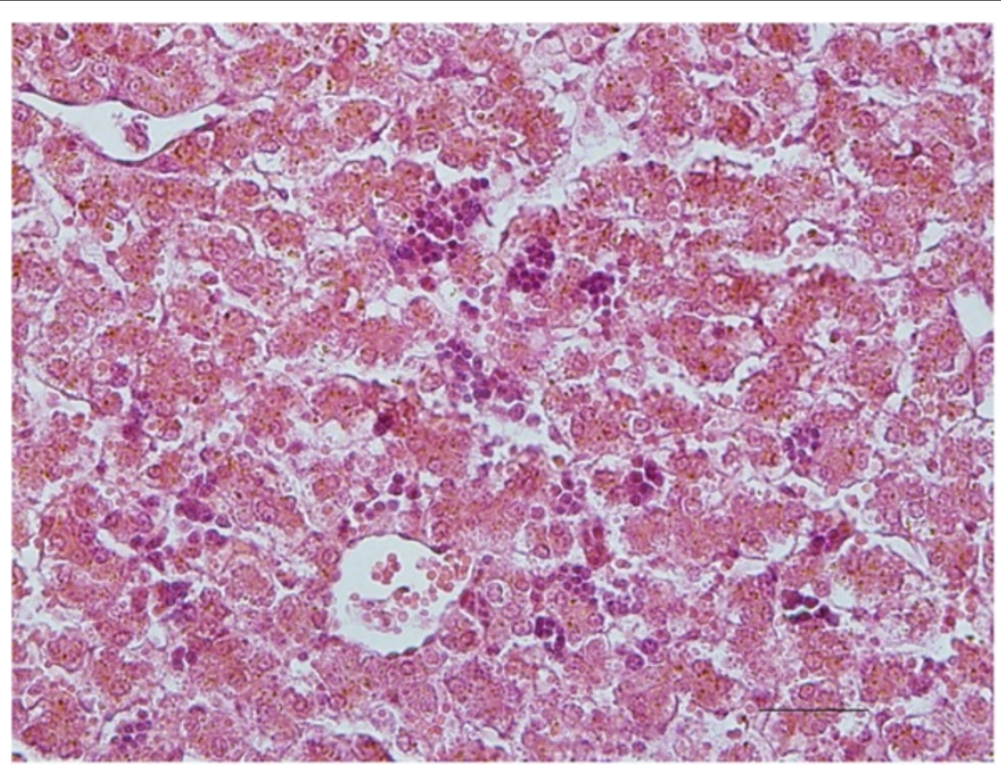

Figure 4 Inflammatory processes in the liver parenchyma of fetuses induced by the migration of $T$. vivax. Diffuse hepatocellular necrosis and multifocal mononuclear hepatitis in a fetus aborted in the final trimester of pregnancy. Hematoxilin-eosin, obj. $40 x$, Scale bar $=99 \mu m$. 


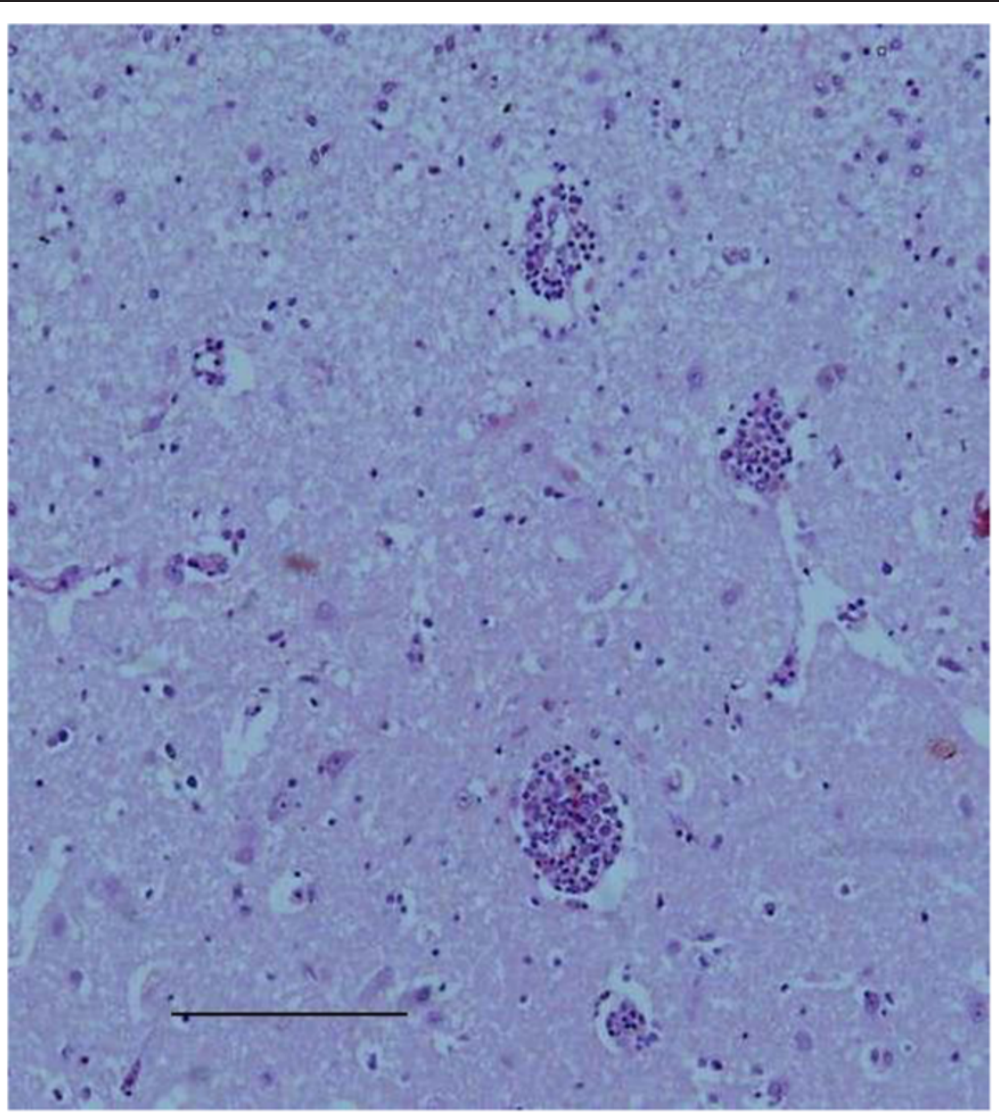

Figure 5 Inflammatory processes in the brain of fetuses induced by the migration of $\boldsymbol{T}$. vivax. Mononuclear multifocal encephalitis in a fetus aborted in the final trimester of pregnancy. Hematoxilin-eosin, obj. 10x, Scale bar $=147 \mu \mathrm{m}$.

\section{Discussion}

Our results indicate that pregnancy changed the clinical aspects of trypanosomiasis, since there was an exacerbation of the infection, manifested by high and persistent parasitemia followed by hyperthermia. Studies evaluating follicular degeneration in goats experimentally infected with $T$. vivax, using the same dose $\left(1.25 \times 10^{5}\right.$ trypomastigotes) and inoculum from the present study, showed high parasitemia and hyperthermia in the acute phase only, whereas in the chronic phase, parasitemia is either

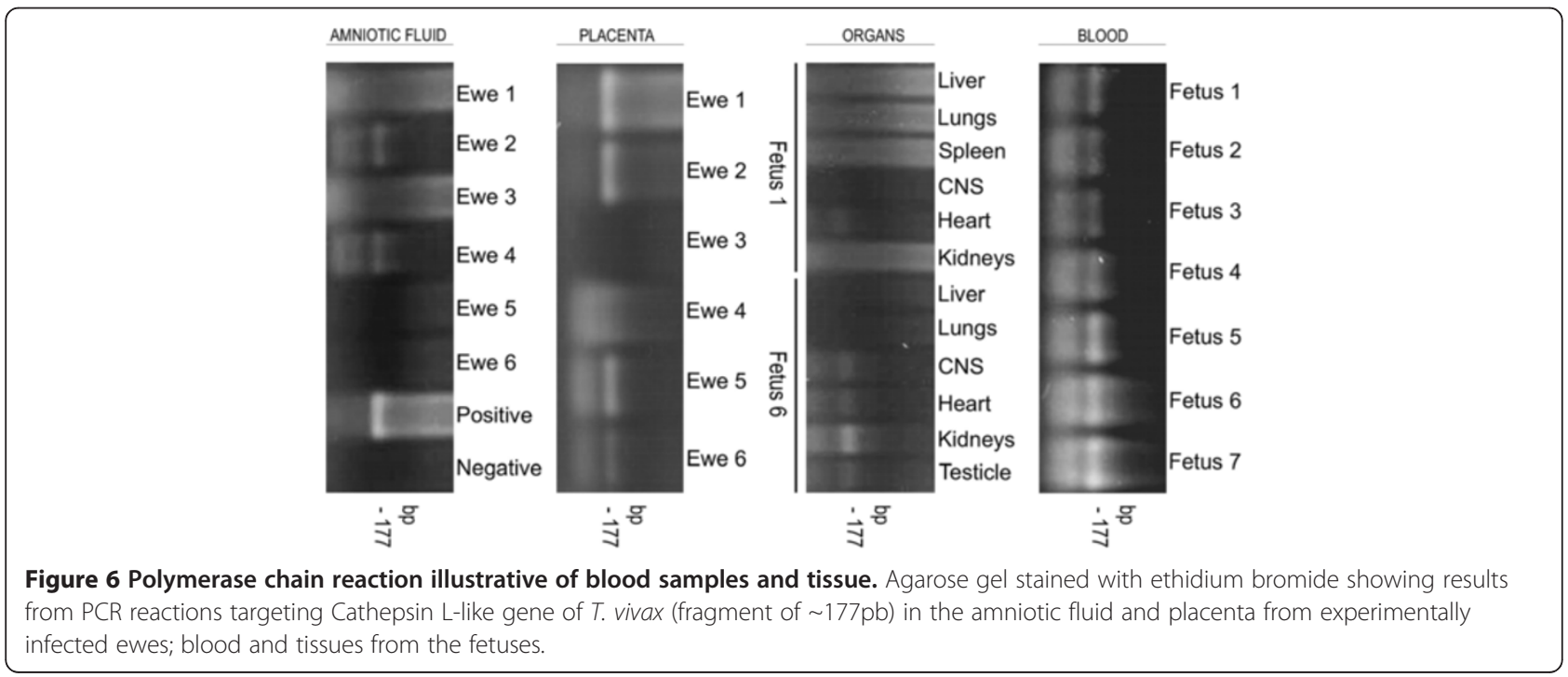


absent or of low intensity. An important feature is that none of the experimental animals died [23].

Mean values of hematocrit ( $\mathrm{PCV}$ ) showed the typical evolution of trypanosomiasis, with a progressive reduction in the values throughout the infection period. Evaluation of the degree of anemia by hematocrit determination has been frequently used in monitoring the evolution of the disease, since this hematological parameter is most frequently changed in animals experimentally or naturally infected by $T$. vivax [24-26]. The hematocrit showed a dramatic decrease in infected ewes from this study, reaching $8 \%$. Low hematocrit is associated with more severe stages of trypanosomiasis and may have contributed to the fatal course of disease in Ewes 1 and 3; and to the reduced body weight of newborn lambs and aborted fetuses.

Pathological consequences of the infection in pregnant females appear to be directly related to the gestational period in which it occurs. In the present study, two ewes infected in the first third of pregnancy presented serious infection and died within 65 days of pregnancy ( $35 \mathrm{dpi}$ ). However, the mortality of the ewes infected in the final third of pregnancy did not occur. Two of those ewes aborted, and another delivered a live lamb; but the weak offspring died five days after birth. The negative effect of trypanosomiasis in pregnant females is probably a consequence of the low immunity in this period associated to hematological and biochemical alterations promoted by the hemoparasite, that also increases the metabolic needs of the pregnant female [27-29]. In addition, the ovine placenta starts secreting progesterone around day 55 , which is sufficient to maintain pregnancy in most ewes when the corpus luteum is removed [30]. Therefore, the damage to the placenta caused by the protozoa may promote the insufficient placental secretion of progesterone and the consequent interruption of pregnancy.

The evaluation of blood glucose concentration has been applied as an indicator of energy metabolic activity. Thereby, the metabolism of pregnant ewes is characterized by high glucose requirements [31]. The effect of $T$. vivax on the energetic metabolism in goats promoted an increase of $25 \%$ in the energy requirements for maintenance. Hypoglycemia is a common finding in acute trypanosomiasis, and is attributed to energy expenditure caused by hyperthermia and blood glucose consumption by trypanosomes [32]. In this study, hypoglycemia revealed to be an important biochemical change observed in the infected groups. Thus, the combination of increased energy demands in pregnancy associated with a negative energy balance promoted by the infection is incompatible with the maintenance of fetal development in pregnant ewes. In addition, fetal fructose is produced by the placenta from glucose, and comprises about $70-80 \%$ of fetal blood sugar. The values of fetal fructose are correlated with the maternal glucose levels, and the maintenance of high concentrations can be seen as an indicator of ideal placental function [33]. Another important metabolic alteration in the infection is the increase in protein catabolism, which is evidenced by the significant decrease of serum total protein and increased urea [34]. A similar trend was observed in this study, in which low serum levels of total protein and high levels of urea were observed in the infected ewes.

Another systemic alteration observed in infected pregnant ewes was the progressive loss of body condition, which was manifested by low body scores achieving the lower limit of 1.5 (Ewe 1 and 3). Whatever the cause, small ruminants with a body condition of 1.5 are nine times more prone to abort compared with those in good body condition [35]. Other systemic manifestations observed in this group, and found in the reviewed literature as capable of promoting abortion, are hyperthermia and anemia [36,37]. The reduction in serum progesterone is another cause of maternal origin that can trigger abortion. In this study, it was observed that the serum levels of progesterone of infected ewes were significantly lower than those observed in the control group. It is known that the decrease in progesterone may result in disruption of pregnancy and promotes the expulsion of the dead fetus. In female animals, hormonal disorders in trypanosomiasis caused by $T$. vivax occur due to degeneration of the hypothalamus, pituitary, and gonads; which results in disruption of hormonal secretion, and consequent diminishing plasma concentrations of those hormones, which are fundamental for the reproductive processes, including pregnancy [38]. Another hypothesis for the abortions consists in the occurrence of maternal hypoglycemia and, consequently, fetal hypoglycemia. This event is followed by the successive events of an increase of corticosteroids, estrogen, and prostaglandin, causing luteolysis and abortion [39].

The demonstration of parasite DNA by PCR in the placenta, blood, and tissue from aborted fetuses and stillbirths suggest that the protozoan traverses the maternal bloodstream. Thus, the infection invades the pregnant uterus, causing placental damage, and spreads into the blood and fetal tissues. Our histopathological results showed pericarditis, hepatitis, and encephalitis in the fetuses, therefore classifying these abortions as of infectious origin [40].

The abortion or birth of weak lambs may also be explained by placental insufficiency. Reproductive failure due to chorionic epithelial damage may occur due to inadequate nutrition or fetal oxygenation. In such cases, the fetus suffers anoxia, releasing the adrenocorticotrophic hormone with the subsequent release of fetal cortisol, which stimulates the production of estrogen and prostaglandin F2 $\alpha$ by the placenta. This event 
results in luteolysis, with a consequent decrease in progesterone [41]. The presence of the DNA of T. vivax in the placenta associated with its damage suggests that the parasite has an important role in the pathogenesis of placental dysfunction and abortion.

The detection of $T$. vivax in the placenta, amniotic fluid, fetal blood, and tissues is an unprecedented event, and confirms the first diagnosis of the transplacental transmission through detection of the parasite DNA by PCR in ewes. Although little investigated, transplacental transmission was confirmed for the first time in 1972 by the finding of large numbers of trypanosomes in the blood four hours after the birth of lambs from experimentally inoculated ewes with T. vivax in the final trimester of gestation [16]. Later, there was the confirmation of the transplacental transmission of $T$. vivax in cattle by the detection of high parasitemia in a calf born from an infected cow in the same period of pregnancy [42]. In Venezuela, congenital transmission was also observed in a calf, in which parasitemia and anti-T. vivax antibodies were detected by indirect immunofluorescence [43]. Recently, in Brazil, the probable transplacental transmission was recognized in four three-day-old calves with high parasitemia and born from chronically infected cows [15]. These authors attribute the high prevalence of trypanosomiasis by $T$. vivax in Northeastern Brazil to the transplacental transmission, as the regional climate (hot and dry) does not favor the development of host insects during most of the year.

In naturally infected flocks and herds, the transplacental transmission of the parasite is not well known and is underestimated by farmers and practitioners. The published cases of placental transmission by $T$. vivax do not describe lesions and parasitism of the placenta, and show no morphological evidence of the infection in the fetus. In this study, the occurrence of transplacental transmission in ewes was based on the identification of pathological lesions, suggesting protozoan infection, and also by the detection of the parasite's DNA in the placenta, amniotic fluid, blood, and tissues from aborted fetuses and recently dead neonates. The transplacental transmission of $T$. vivax is unquestionable, as well as its effects on fetuses and newborns, which may occur in the initial or final third of gestation. It is likely that this type of transmission contributes to the survival of the parasite and the spread of infection in herds, and is also associated with cases of abortion, premature births, low birth weight, and perinatal mortality. These facts are often reported during the outbreaks of $T$. vivax infection in the Brazilian semiarid region $[15,18,20]$.

Our experiment confirms the importance of $T$. vivax as a causative agent of abortion and perinatal mortality, as previously demonstrated in the outbreaks of infection in cattle, ewes, and goats in the Brazilian semiarid region
$[14,19,20,44]$. Our data suggest that T. vivax is able to cause abortions or perinatal mortality in different ways. In fact, the reproductive disturbances caused by the parasite may be multifactorial, since maternal systemic effects and injury of the placenta and fetus were observed.

\section{Abbreviations}

PCR: Polymerase chain reaction; PCV: Packed cell volume;

DNA: Deoxyribonucleic acid; UFERSA: Federal Rural University of the Semiarid; EDTA: Ethylenediaminetetraacetic acid disodium; HE: Hematoxylin-eosin method; Dpi: Days post-infection.

\section{Competing interests}

The authors declare that they have no competing interests.

\section{Authors' contributions}

JSB carried out the pathological analyses, conceived the study, and participated in its design and coordination. TMFS, RGO, ACLC, FCL, MFBR and CIAF carried out the experimental infection, clinical exams, and drafted the manuscript. MMGT and CMFR carried out the DNA analysis. JSB, WACC and TMFS performed the statistical analysis. All authors read and approved the final manuscript.

\section{Acknowledgements}

The authors would like to acknowledge the Federal Rural University of the Semiarid (UFERSA), University of São Paulo (USP) and Federal University of Minas Gerais (UFMG) contribution to the provision of laboratories and the availability of the structure.

\section{Author details}

'Department of Animal Sciences, Federal Rural University of the Semiarid (UFERSA), Av. Francisco Mota 572, Mossoró, RN 59625-900, Brazil. ${ }^{2}$ Department of Parasitology, Institute of Biological Sciences, University of São Paulo (USP), São Paulo, SP 05508-900, Brazil. ${ }^{3}$ Department of Parasitology, Institute of Biological Sciences, Federal University of Minas Gerais (UFMG), Belo Horizonte, MG 486, Brazil.

Received: 30 April 2012 Accepted: 10 December 2012 Published: 4 January 2013

\section{References}

1. Gardner PR, Assoku RKG, Whitelaw DD, Murray M: Haemorrhagic lesions resulting from Trypanosoma vivax infection in Ayrshire cattle. Vet Parasitol 1989, 31:187-197.

2. Dávila AMR, Silva RAMS: Animal trypanosomiasis in South America. Current status, partnership, and information technology. Ann N Y Acad Sci 2000, 916:199-212.

3. Silva RAMS, Seidi A, Ramirez L, Dávila AMR: Trypanosoma evansi and Trypanosoma vivax: biology, diagnosis and control. Embrapa Pantanal 2002, 141:137.

4. Adams ER, Hamilton PB, Gibson WC: African trypanosomes: celebrating diversity. Trends Parasitol 2010, 26:324-328.

5. Vargas TM, Arellano SC: La tripanosomiasis bovina en América Latina y el Caribe. Vet Montividel 1997, 33:17-21.

6. Jones T, Dávila AMR: Trypanosama vivax: out of Africa. Trends Parasitol 2001, 17:99-101.

7. Anosa VO: Diseases produced by Trypanosoma vivax in ruminants, horses and rodents. Zentralbl Veterinarmed B 1983, 30:717-741.

8. Leger M, Vienne M: Epizootie à trypanosomes chez les bovidés de la Guyane Française. Bull Soc Pathol Exot 1919, 12:258-266 (in French).

9. Zapata A: La affection de los ganados ilamada vulgarmente "huequera", "secadera", "cachohueco". Rev Med Vet 1931, 3:165-180 (in Portuguese).

10. Otte MJ, Abuabara JY, Wells EA: Tripanosoma vivax in Colombia: epidemiology and production losses. Trop Anim Health Prod 1994, 26:146-156

11. Silva RAMS, Morales G, Eulert E, Montenegro RY, Ybañez R: Outbreaks of trypanosomosis due to Trypanosoma vivax in cattle in Bolivia. Vet Parasitol 1998, 76:153-157. 
12. Silva AS, Costa MM, Polenz MF, Polenz CH, Teixeira MMG, Lopes STA, Monteiro SG: Primeiro registro de Trypanosoma vivax em bovinos no Estado do Rio Grande do Sul. Brasil. Cienc Rural 2009, 39:2550-2554 (in Portuguese).

13. Paiva F, Lemos RAA, Nakasato L, Mori AE, Brum KB, Bernardo KC: Ocorrência de Trypanosoma vivax em bovinos do Estado de Mato Grosso do Sul, Brasil. I - Acompanhamento clínico, laboratorial e anatomopatológico de rebanhos infectados. Rev Bras Parasitol Vet 2000, 9:135-141 (in Portuguese).

14. Pimentel Dde $S$, Ramos CAN, Ramos RAN, de Araújo FR, Borba ML, Faustino MAG, Alves LC: First report and molecular characterization of Trypanosoma vivax in cattle from state of Pernambuco, Brazil. Vet Parasitol 2012, 185:286-289.

15. Batista JS, Rodrigues CMF, Olinda RG, Silva TMF, Vale RG, Câmara ACL, Rebouças RES, Bezerra FSB, García HÁ, Teixeira MMG: Highly debilitating natural Trypanosoma vivax infections in Brazilian calves: epidemiology, pathology, and probable transplacental transmission. Parasitol Res 2012, 110:73-80.

16. Losos GJ, Ikede BO: Review of pathology of diseases in domestic and laboratory animals caused by Trypanosoma congulense, T. vivax, T. rhodesiense and T. gambiense. Vet Pathol 1972, 9:1-71.

17. Ogwu D, Njoku CO, Osori DIK: Effects of experimental Trypanosoma vivax infection on first-, second-, and third-trimester pregnancy in heifers. Theriogenology 1986, 25:383-398.

18. Batista JS, Riet-Correa F, Teixeira MMG, Madruga CR, Simões SDV, Maia TF: Trypanosomosis by Trypanosoma vivax in cattle in the Brazilian semiarid: description of an outbreak and lesions in the nervous system. Vet Parasitol 2007, 143:174-181.

19. Batista JS, Oliveira AF, Rodrigues CMF, Damasceno CAR, Oliveira IRS, Alves HM, Paiva ES, Brito PD, Medeiros JMF, Rodrigues AC, Teixeira MMG: Infection by Trypanosoma vivax in goats and sheep in the Brazilian semiarid region: from acute disease outbreak to chronic cryptic infection. Vet Parasitol 2009, 165:131-135.

20. Galiza GJ, Garcia HA, Assis AC, Oliveira DM, Pimentel LA, Dantas AF, Simões SV, Teixeira MMG, Riet-Correa F: High mortality and lesions of the central nervous system in trypanosomosis by Trypanosoma vivax in Brazilian hair sheep. Vet Parasitol 2011, 182:359-363.

21. Freitas Júnior JE, Rocha Júnior VR, Rennó FP, de Mello MTP, Carvalho AP, Caldeira LA: Efeito da condição corporal ao parto sobre o desempenho produtivo de vacas mestiças Holandês $\times$ Zebu. Rev Bras Zootec 2008, 37:116-121 (in Portuguese).

22. Cortez AP, Rodrigues AC, Garcia HA, Neves L, Batista JS, Bengaly Z, Paiva F, Teixeira MM: Cathepsin L-like genes of Trypanosoma vivax from Africa and South America - characterisation, relationships and diagnostic implications. Mol Cell Probes 2009, 23:44-51.

23. Rodrigues CMF, Olinda RG, Silva TMF, Vale RG, Silva AE, Lima GL, Garcia HÁ Teixeira M, Batista JS: Follicular degeneration in the ovaries of goats experimentally infected with Trypanosoma vivax from the Brazilian semiarid region. Vet Parasitol 2013, 191:146-153.

24. Pellín CES, González FAG, Baldizán G, Liñarez FFM: Comportamiento parasitológico, clínico y hematológico em ovinos infectados experimentalmente con un aislado venezolano de Trypanosoma vivax. Vet Tropical 2003, 28:79-92. in Portuguese.

25. Valera Z, Parra O, Alvarado M, Barboza G, Escalona F, Ramírez R: Efecto de la infección experimental com Trypanosoma vivax sobre parâmetros hematológicos em ovinos. Revta Cient 2005, 15:412-420 (in Portuguese).

26. Batista JS, Correa FR, Barbosa RC, Guerra JL: Experimental infection by Trypanosoma vivax in sheep. Pesq Vet Bras 2006, 26:31-37.

27. Stephen LE: Trypanosomisis: a veterinary perspectiva. New York: Pergamon Press; 1986.

28. Adeiza AA, Maikai VA, Lawal Al: Comparative haematological changes in experimentally infected Savannah brown goats with Trypanosoma brucei and Trypanosoma vivax. Afr J Biotechnol 2008, 7:2295-2298.

29. Ohaeri CC, Eluwa MC: Abnormal biochemical and haematological indices in trypanosomiasis as a threat to herd production. Vet Parasitol 2011, 177:199-202.

30. Weems YS, Kim L, Tsuda V, Yin C, Weems CW: What regulates placental steroidogenesis in 90-day pregnant ewes? Prostaglandins Other Lipid Mediat 2007, 84:54-65.

31. Rook JS: Pregnancy toxemia of ewes, does and beef cows. Vet Clin North Am Food Anim Pract 2000, 16:293-317.
32. Kadima KB, Gyang EO, Saror DI, Esievo KAN: Serium biochemical values of Trypanosoma vivax infected cattle and effects of lactose in saline infusion. Veterinarski Arhiv 2000, 70:67-74

33. Jainudeen MR, Hafez ESE: Gestação, Fisiologia Pré-Natal e Parto. In Reprodução animal. Edited by Hafez ESE. Barueri: Editora Manole; 2000.

34. Van Dam JTP, Heide DV, Hela W, Ingha TSGAM, Verstegena MWA, Wensinga T, Zwart D: The effect of Trypanosoma vivax infection energy and nitrogen metabolism and serum metabolites and hormones in West African Dwarf goats on different food intake levels. J Anim Sci 1996, 63:111-121.

35. Mellado M, Valdez R, Lara LM, García JE: Risk factors affecting conception, abortion and kidding rates of goats under extensive conditions. Small Ruminant Res 2004, 55:191-198.

36. Parkinson T: Specific infectious diseases causing infertility and subfertility in cattle. In Veterinary reproduction and obstetrics. Edited by Noakes DE, Parkinson TJ, England GCW. London: Saunders Elsevier; 2009.

37. Nascimento EF, Santos RL: Patologias do útero gestante. In Patologia da Reprodução dos Animais Domésticos. Edited by Nascimento EF, Santos RL. Rio de Janeiro: Guanabara Koogan; 2003.

38. Sekoni VO: Reproductive disorders caused by animal trypanosomiases: a Review. Theriogenology 1994, 42:557-570.

39. Wentzel D: Non-infection abortion in Angora goats, International Conference On Goat Production And Disease: 10-15 January of 1982. Tucson: Arizona: University of Arizona; 1982.

40. Cabral AD, Camargo CN, Galleti NTC, Okuda LH, Pituco EM, Del Fava C: Diagnosis of Neospora caninum in bovine fetuses by histology, immunohistochemistry, and nested-PCR. Rev Bras Parasitol Vet 2009, 18:14-19.

41. Dubey JP, Buxton D, Wouda W: Pathogenesis of bovine neosporosis. J Comp Pathol 2006, 134:267-289.

42. Ogwu D, Njoku CO, Osori DIK: Effects of experimental Trypanosoma vivax infection on first, second and third trimester pregnancy in heifers. Theriogenology 1986, 25:238-396.

43. Melendez DR, Forlano M, Figueroa W: Perinatal infection with Trypanosoma vivax in a calf in Venezuela. J Parasitol 1993, 79:293-294.

44. Batista JS, Bezerra FSB, Lira RA, Carvalho JRG, Rosado Neto AM, Petri AA, Teixeira MMG: Clinical, epidemiological and pathological signs of natural infection in cattle by Trypanosoma vivax in Paraíba Brazil. Pesq Vet Bras 2008, 28:63-69.

doi:10.1186/1297-9716-44-1

Cite this article as: Silva et al.: Pathogenesis of reproductive failure induced by Trypanosoma vivax in experimentally infected pregnant ewes. Veterinary Research 2013 44:1.

\section{Submit your next manuscript to BioMed Central and take full advantage of:}

- Convenient online submission

- Thorough peer review

- No space constraints or color figure charges

- Immediate publication on acceptance

- Inclusion in PubMed, CAS, Scopus and Google Scholar

- Research which is freely available for redistribution 